\title{
REGIONAL DIMENSIONS OF KNOWLEDGE PROCESSES IN THE SECTORS OF TRANSPORT AND LOGISTICS AND ICT IN THE ZILINA REGION
}

The paper presents the results of the APVV project - Regional dimensions of knowledge economy, which was solved in the Department of Communications, Faculty of Operation and Economics of Transport and Communications, University of Zilina during 2008 - 2011. The paper briefly describes logistics sector and ICT sector in the Zilina region and their knowledge management. Significant results of the project were achieved through knowledge biography, which maps creation, processing and dissemination of knowledge. Based on this methodology the case studies in selected logistics and ICT enterprises in the Zilina region were created. The results of sectoral analysis and knowledge biographies of enterprises resulted into finding that knowledge is the most strategic "material"; learning is a critical process for maintaining competitiveness of enterprises and that relevant aspects together create key mechanism for regional differentiation.

Keywords: Knowledge economy, knowledge processes, knowledge biography.

\section{Introduction}

Knowledge economy is economy based on the ability to produce, use and disseminate new knowledge. It is a collective process with many participants within enterprises, and also from narrower or wider environment of enterprise, with knowledge [1]. Within researching regional dimension of these processes we can see different symptoms and identify a new type of gap, which lies in low ability of regions (as systems of interconnected entities) to adapt to economic changes. The REDIPE project - Regional dimension of knowledge economy (APVV-0230-07) was coordinated by the University of Economics in Bratislava, Faculty of National Economy, Department of Public Administration and Regional Development; and the University of Zilina, Faculty of Operation and Economics of Transport and Communications, Department of Communications was a project partner. The main aim of the project was to explore regional aspects of knowledge economy from different points of view and to set recommendations for implementation of development policy in regions. During solving the project, the research team achieved deeper understanding of knowledge creation and dissemination processes in specific regions; decisionmaking and planning processes at regional and national levels were improved and obtained knowledge was implemented into education activities at the University of Zilina. Within this project, for the first time in Slovakia, knowledge economy on regional level with application methodology based on multidimensional analysis of sectors and regions in order to identify key instruments of the knowledge economy development in regional context was explored. Based on empirical research, new information referring to behav- iour of enterprises in connection to creation, processing and dissemination of knowledge was achieved. So far, this type of research had absented, thus it was not possible to diagnose and compare process of developing knowledge economy at micro level within selected sectors, as well as make a comparison with similar processes abroad [2].

\section{The main goals}

The main goal of the paper is to provide brief results of the REDIPE project - Regional dimensions of knowledge economy. The intermediate goal of the paper is to provide results of the sectoral analysis of two selected sectors, as well as the introduction of a specific research method, based on the enterprise knowledge biography. There are also two case studies in the paper. These case studies document the way of knowledge diagnostics, knowledge processing and knowledge dissemination in enterprises in the regional, national and international contexts.

\section{Methodology - sectoral analysis in a selected area and knowledge biography}

As mentioned above, the paper presents the result of the REDIPE project to which a selection of methods also corresponds. In order to meet aims of the paper, it was considered to be a primary research whose results allowed to create SWOT analysis of selected sectors in terms of knowledge economy. For monitoring knowl-

\footnotetext{
* Tatiana Corejova, Maria Rostasova, Alena Chrenkova, Emilia Madudova

Department of Communications, Faculty of Operation and Economics of Transport and Communications, University of Zilina, Slovakia,

E-mail: tatiana.corejova@fpedas.uniza.sk
} 
edge dynamics in selected enterprises specific methodology based on qualitative research processed as knowledge biographies of enterprises was applied. The aim of the knowledge biographies creation is to analyse knowledge dynamics and its connections within the enterprise and between enterprises themselves and to understand the complex of events, participants and flows which create knowledge dynamic, which is necessary for ensuring a change of the product, process and organization [3].

Methodology of knowledge biography lies in the following six steps:

I. Finding a suitable candidate for knowledge biography - it means selection of a sufficient number of enterprises with territorial knowledge dynamics as suitable candidates for creating knowledge biography; identification of innovative and strategic changes at the enterprise level.

II. Establishing initial contact (initial meeting) - the aim is to create foundation for the future cooperation in order to obtain general information about the enterprise, its innovation activities and links to the region.

III. Initial verbal interview with a representative of the enterprise - for gathering information necessary for knowledge biography. The obtained data include the main participants, milestones and barriers of knowledge processes. This creates "story of development process of enterprise realized through creation, processing and dissemination of knowledge", defining types of knowledge, proximities, internal and external links.

IV. The second interview in the enterprise - is based on deepening understanding of knowledge dynamics in the enterprise; subsequently a first draft of network map resulting from the results of interviews and other data obtained during the previous steps is created. The interview includes questions about time and content focus of change, internal and external participants of change, initiators of change and also about the way of knowledge transfer into the enterprise.

V. The interview with external participants of knowledge dynamic of enterprise - in order to create comprehensive case study, where respondents are customers, suppliers, institutions of supporting infrastructure, public administration, members of clusters, etc., who were important partners in the innovation process and affect the innovation process in the enterprise [3].

For evaluation of knowledge biography and creation of the knowledge model several types of maps were created:

a) Map of milestones in the creation, processing, utilization and dissemination of knowledge in the enterprise - is created based on the information included into knowledge biography of the enterprise. Horizontal division identifies the location where the processes of creation, processing, utilization and dissemination of knowledge (internal or external) were realised and a vertical division represents various phases of knowledge process. The time indicated in the map reflects a difficulty of meeting different stages of knowledge process in the enterprise.

b) Map of knowledge processes in the enterprise - describes participants of the process of creation, processing, utilization and dissemination of knowledge throughout the life of knowledge and innovation. It is created in relation to particular horizontal and vertical fields of the map (the example of the map is illustrated in Fig. 1).

c) Time-spatial map of knowledge processes in the enterprise is produced using $3 \mathrm{D}$ presentation and represents a time and spatial map of relations and processes in knowledge management (the example of the map in a selected enterprise is shown in Fig. 2) [3].

\section{Results}

\subsection{Framework characteristics of the ICT sector in the Zilina region in the area of creation, processing and dissemination of knowledge}

Experts and founders of the major enterprises of the ICT sector in the Zilina region have previously worked at the VUVT Zilina. The main customers of ICT enterprses in the Zilina region are not only from the Zilina region, but also from outside the region. In terms of a geographic market definition, the market is described by the ICT enterprises as global. The global market definition implies major suppliers from the region and outside the region. The $90 \%$ of respondents think that the main impulse to innovation is a customer. A significant importance is attributed by ICT enterprises to informal relationship. Regional cooperation is mainly reflected in the ICT cluster [4]. The brief SWOT analysis of ICT sector in the Zilina region, which resulted from the performed sectoral analysis, with highlighted strengths and weaknesses, opportunities and threats is in Table 1.

\subsection{Framework characteristics of transport and logistics sector in the Zilina region in the area of creation, processing and dissemination of knowledge}

Enterprises draw inspiration for creation, processing and dissemination of knowledge mainly from neighbouring regions, with which they cooperate and have good relationship. Participation in professional events, literature and membership in professional organizations also contribute to creation and processing of knowledge. In comparison with the 90's of the last century, it appears that the area of knowledge dissemination has been influenced mostly by entry of enterprises with foreign participation in a logistics sector [5]. They bring inspiration for change, capital and knowledge (for example about new management systems, etc.). In national as well as regional contexts enterprises were profiled, which can be considered as leaders in processing and dissemination of knowledge (e.g. Logisped, Cargo, etc.). Development in the sector was also influenced by differences in legislation and technological level of providing services. In transport and logistics sectors, there is an intense competition and the market is highly fragmented. The process of creating preconditions for realization the knowledge process, associated with creation of innovation in transport and logistics sector does not have significant particularities compared to other sectors [6]. 


\begin{tabular}{|c|c|}
\hline Strengths & Weaknesses \\
\hline $\begin{array}{l}\text { - Skilled labour force (transport, communications, postal sector, ICT } \\
\text { sector, logistics) } \\
\text { - High concentration of IT professional labour force } \\
\text { - Creativity - new original ideas } \\
\text { - Know-how - essential for the regional development } \\
\text { - Network of good class suppliers with high value added for customers } \\
\text { - Region is defined as the centre of "IT brains“ }\end{array}$ & $\begin{array}{l}\text { - Insufficient know-how of professional and general public in the area of } \\
\text { ICT cluster research } \\
\text { - Inconsistent employees (do not think as a customer) } \\
\text { - Hierarchy of power can be felt in the sector of ICT } \\
\text { - Short product life }\end{array}$ \\
\hline Opportunities & Threats \\
\hline $\begin{array}{l}\text { - The existence of the University of Zilina - Professional employee } \\
\text { development at the University of Zilina for the ICT sector } \\
\text { - Arrival of new investors } \\
\text { - In general - tendency of young people to achieve success } \\
\text { - General tendency of industry to expanse } \\
\text { - The growth of e-business at the market } \\
\text { - Encouraging the EU to integrate the ICT sector and to formalize the } \\
\text { clusters } \\
\text { - Software development solutions worldwide as an example of the best } \\
\text { practice }\end{array}$ & $\begin{array}{l}\text { - Sensitivity of the sector to the economic situation } \\
\text { - An increase of management at humanities universities in the Slovak } \\
\text { Republic - poor functional education system at the Slovak universities } \\
\text { (lack of practice) } \\
\text { - Rapid and intense development (outside the region) in the ICT sector } \\
\text { - Strong competitive environment in the area of ICT } \\
\text { Small national market - low market potential }\end{array}$ \\
\hline
\end{tabular}

Source: [4]

\begin{tabular}{|c|c|}
\hline Strengths & Weaknesses \\
\hline $\begin{array}{l}\text { - Quick establishment of enterprises in the labour market } \\
\text { - High flexibility of enterprises in the transport and logistics sectors } \\
\text { - Modern rolling stock } \\
\text { - Transition to corporate social responsibility }\end{array}$ & $\begin{array}{l}\text { - Lower level of employees' motivation to influence their passive } \\
\text { approach to work } \\
\text { - Inefficient and unsystematic fight with competition }\end{array}$ \\
\hline Opportunities & Threats \\
\hline $\begin{array}{l}\text { - Geographic location of the region } \\
\text { - Workforce skilled enough in the labour market, possibility for } \\
\text { permanent education } \\
\text { - Creation of appropriate conditions by the state for business in the } \\
\text { transport and logistics sectors } \\
\text { - Pan-European and global levels of know-how in the sector } \\
\text { - High customer loyalty in the transport and logistics sectors } \\
\text { - Cheap workforce in the region } \\
\text { - Support of the development of integrated transport system by national } \\
\text { and regional governments, } \\
\text { - Growth in demand for transport and logistics services }\end{array}$ & $\begin{array}{l}\text { - Pressure from customers on quality of services, } \\
\text { - Lack of transparency between orders of the services provided } \\
\text { - Existing competition in national and international contexts in the } \\
\text { transport and logistics sectors } \\
\text { - Passive attitude of employees } \\
\text { - Increasing input prices } \\
\text { - Negative effects of weather on businesses in the transport and logistics } \\
\text { sectors }\end{array}$ \\
\hline
\end{tabular}

Source: [7]

The brief SWOT analysis of transport and logistics sector in the Zilina region, which resulted from the realized sectoral analysis, with highlighted strengths and weaknesses, opportunities and threats is pictured in Table 2 .

Sectoral analysis in the Zilina region was a base for creating case studies. Within them knowledge biographies for selected enterprises were created. Examples of these studies from both sectors are in the subchapters 4.3 and 4.4 .

\subsection{Case study of Scheidt \& Bachmann Slovakia s.r.o.}

The enterprise Scheidt \& Bachmann Slovakia s.r.o., is a related enterprise managed by two commissioners. General agreement between the controlling enterprise and related enterprise Scheidt \& Bachmann Slovakia, s.r.o., can be defined as an essential specification of mutual cooperation. The price of ordered solutions is bargained individually with a controlling enterprise for every single order. Initially, the controlling enterprise defines the project problems and then managers from the related enterprise appraise the 
time and a number of developers needed for the project. Indeed, negotiations regarding the price are not concluded with the first proposal. The payments for the finished projects are paid out only after the projects are finished. The time needed for the project realization varies. The simplest project requires a couple of weeks but some others take up to a few years. Therefore, the related enterprises realize a number of various projects at the same time. Despite the fact that Scheidt \& Bachmann Slovakia s.r.o. finances the research activities, the enterprise does not have its own research departments.

During the development employees often have to face problems for solving of which they need more other professionals. In this case Scheidt \& Bachmann Slovakia s.r.o. assigns the problem tasks to additional subjects, particularly to the University of Zilina. There are four independent divisions in this enterprise. These divisions develop, produce and distribute systems for car parks (parkings) and relax centers, systems for railway security devices, systems for passenger care, systems for petrol station, etc.

At the beginning the enterprise profile graded as "a softwarehouse" for all four divisions. After some time the enterprise strategically increased its range of activities and created a division of operation devices. Scheidt \& Bachmann Slovakia s.r.o. also specializes in control software development for products of a parent firm. Transport means are more and more intelligent, their software is becoming more and more difficult and it takes some functions which were previously done mechanically. The enterprise Scheidt \& Bachmann Slovakia s.r.o. employs 2000 employees. Within this number there is 1200 employees in the parent firm and in its daughter firm, Transport systems Scheidt \& Bachmann, s.r.o., Zilina it employs 200 employees. The enterprise Scheidt \& Bachmann Slovakia s.r.o. is a member of ICT cluster. In the 70's the enterprise produced mechanical printers for the city buses [8].

Contemporary printing and encoding device for transportation tickets presents an innovation of the former printer. The innovation represents an electronic system which expanses product features of the former printer. The main reason regarding this shift leans on technical development (technological changes) that affected the product innovation pressure. Whereas the innovation was affected by technical development, marketing research was not realized. The main innovator in the innovation was the top management of Scheidt \& Bachmann Slovakia s.r.o. The innovation was funded from the enterprise financial resources. The enterprise Scheidt \& Bachmann Slovakia s.r.o. did not apply for public funds (grant, project).

Phase 1: Commencement of the idea, characteristic of features of a new (innovated) product, selection of a convenient partner, assignment of the project to the university of Zilina (January - February 2006) - the leader of the innovation was the management of Scheidt \& Bachmann Slovakia s.r.o. The management of Scheidt \& Bachmann Slovakia s.r.o., the chief of development department and the chief of production participated in the innovation. There was no need to hire and train new employees in the first phase.
Phase 2: Development of the initial prototype, completed draft of hardware (6 months), draft of design, development of software (4 months) - The development department participated in the innovation. No additional employees were needed. In the period of March - December 2006, the University of Zilina - the external enterprise was involved into this process. The cooperation rate during the innovation process was regular and intensive. The University of Zilina brought know-how needed for the software and hardware development to the innovation process. We can state that the importance of cooperation between the University of Zilina and Scheidt \& Bachmann Slovakia s.r.o. was significant because the University of Zilina offered the hardware and software to the innovation process. Without this contribution the innovation process could not be realized. The cooperation with the University of Zilina developed on the base of several years of relationship with the university of Zilina and Scheidt \& Bachmann Slovakia s.r.o. The relationship was based on specialists' education and students' study stays. The University of Zilina brought knowledge when creating the hardware and software and it also provided place and equipment because Scheidt \& Bachmann Slovakia s.r.o. could not offer such facilities for the realization of the change [9].

Phase 3: Development of the second prototype (2007) - this phase, in comparison with the previous one, differs in the period of time of the realization which was the period from January December 2007. The leader of the third phase was also the enterprise Scheidt \& Bachmann Slovakia, s.r.o., particularly its development department. There was no need to hire some additional employees. The University of Zilina took part in the innovation process, again. The cooperation rate during the innovation process was regular and intensive. The development of the second prototype proceeded the same way as the development of the first prototype in the first phase.

Phase 4: Project talks with customers, final product marketing $(2008,2009)$ - this phase was performed via meetings between the enterprise and customers when the final product and its benefits and properties were presented to customers. This activity was managed by the employees responsible for marketing of the enterprise.

Phase 5: Batch production (2010) - a final phase was managed by the production department of Scheidt \& Bachmann Slovakia, s.r.o. New employees were hired, including graduates from the University of Zilina. The innovation process as a whole was finished and no innovation extension came into consideration. New employees were trained by Scheidt \& Bachmann Slovakia, s.r.o. The knowledge gathered within this project was disseminated via the presentation of Scheidt \& Bachmann Slovakia, s.r.o. The project was presented at significant national and international conferences, congresses and extra lectures at the University of Zilina [10].

The main hypothesis, which was defined as the statement is as follows: "forwardness of enterprise in the area of creation, processing, exploitation and dissemination of knowledge is heavily influenced by internal and external factors, related to sector characteristic, all 
approved by research through the case study. Despite all this, the enterprise does not play a significant role in the region.”

\section{Specific hypotheses}

I. The process of creation, processing, utilization and dissemination of knowledge in enterprises is not realized purposefully and co-ordinately. The case study did not approve this hypothesis.

II. Innovation process within enterprises is characterized mainly by absorption, combination and knowledge usage, created elsewhere. The hypothesis within this case study was approved.

III. The process of creation, utilization and dissemination of knowledge is characterized by a low rate of cooperation and knowledge supporting usage already created in regions. The hypothesis within this case study was not approved.

IV. Lack of financial funds poses a barrier against creation, gathering and dissemination of knowledge. The hypothesis within this case study was not approved.

V. In general, the state does not donate enterprises with the state funds. The case study approved this hypothesis [10].

\subsection{Case study of Slovenska posta a. s. (Slovak Post, Inc.)}

Slovenska pošta, a. s., is a leading provider of modern communication, distribution and payment services in the domestic market with already created logistic conditions for running business in central and eastern Europe. Innovation explored and solved within the project was based on the fulfillment of aims leading to the systematic quality improvement throughout the project "Service Level Agreements". The project deals with the permanent improvement of quality regarding international and inland first class letters. The main impulse for these changes was quality imbalances at international and inland levels. The project as a whole was aimed at customer's consolation and enterprise stabilities in the already competitive market. The innovation development was funded by Slovenska posta, a. s., no other donations were applied.

The solution is innovative in the fact that through the "statement" we shifted the fulfillment of quality to an employee because this employee might be a kind of a potential source of a poor quality. The main principle was to find the method to fulfill the quality standard. So, for instance, if the quality standard has to be fulfilled at $96 \%$ as a whole and the time for mail delivery is kept, then the logistics department must achieve the standard of $98.5 \%$. The main impulse for the change was the appearance of variation in quality at international and national levels in the area of correspondence. The inspiration for the change was the fact that customers compare the quality of service of Slovenska posta, a. s. with other postal service providers and Slovenska posta, a. s. has to succeed in the competition [10].

Time and content development of the innovation process proceeded in three main phases listed below.

Phase 1: It represented a creation of the idea, creation of steering committee for service quality assurance, work team for service quality secure (2006). In this phase, the innovation was managed by the top management of SP, a.s. The innovation carried out the following external and internal studies aimed at the service quality provided, among others, by the University of Zilina. Into the innovation process the whole enterprise SP, a. s. was involved, particularly all top directors from all the departments. The education of employees was provided by the enterprise. Two external companies participated in the innovation process: the Austrian Post - an international transit region, the Hungarian Post (Budapest); the level of participation was determined according to the process demands. These external movers found their place by exposing the innovation principle and presented a significant support for carrying it out. The additional aspects that significantly affected the innovation process were: the change of customers' behaviour and important technological changes in a postal sector, these aspect have occurred $t$ in the recent years.

Phase 2: Solution statement - created the first version of the "Service Level Agreements" project, regarding first class international and domestic intercourses in the year 2008. Both the steering committee and work team were set up to maintain the service quality. Two external companies participated in the innovation process: the Austrian Post - an international transit region, the Hungarian Post (Budapest), the level of participation was determined according to the process demands.

Communication throughout the process was irregular. The innovation process affected the entire trend in the field of postal services, which aimed to improvement of service quality.

Phase 3: Additional development of product - this phase presents the updating for the years 2009 up to 2010 and still running in the year 2009. A change in this phase was managed by the top management with participation of all the subjects. There was no additional need for external partners. The innovation process continually affected the steadily changing behaviour of customers towards the improvement of service quality, technological changes, global trends regarding competition in the liberalized postal market.

Nowadays, the project is being periodically updated. Recently, the project "Service Level Agreements" was accepted in the service for EPG, EMS-MS. A further extension of the project will take place only in the future [10].

Fig. 1 presents the chart of knowledge processes within the enterprise.

The main hypothesis: "Forwardness of enterprise in the branch of creation, handling, utilization and spreading of knowledge is heavily influenced by internal and external factors, related with sector characteristic, all approved by case study. Despite all this, the influence of regional dimension was not recognized.

\section{Specific hypotheses:}

I. Creation, processing, utilization and dissemination of knowledge within the enterprises is not realized purposely and coordinated. The case study did not approve this hypothesis. 
Explanation of symbols:

Impulses/effects/measurement

Effects

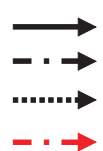

milestone

impulses

Other processes

Not realized yet

$-. \rightarrow$

Descriptions, for example, $01 / 2009$ - date of completion of the phase in knowledge management process

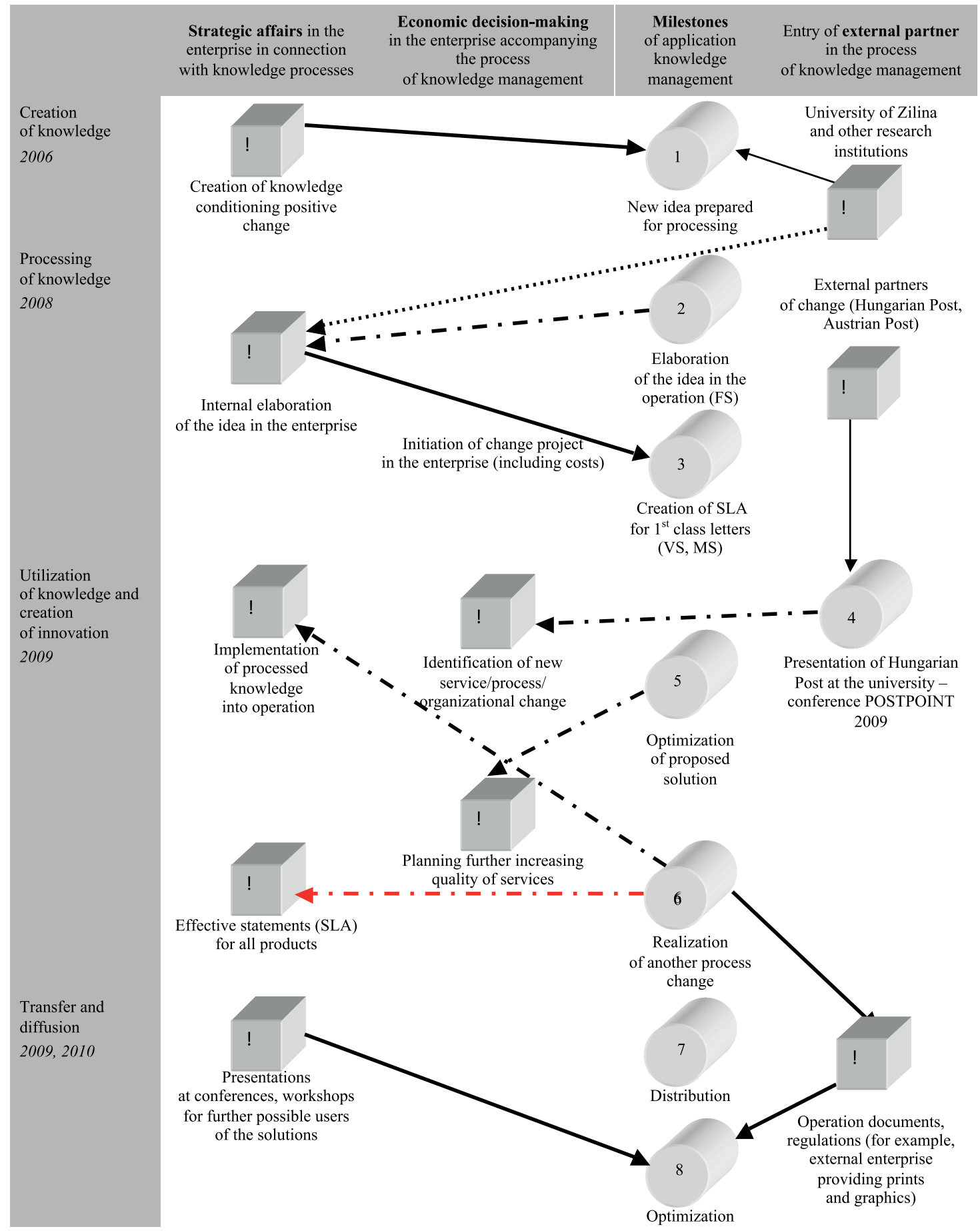

Fig. 1 Map of knowledge processes in Slovenska posta, a. s. [10] 
II. Innovation process within the enterprises is characterized mainly by absorption, combination and knowledge usage, created elsewhere. The hypothesis within this case study was approved.

III. Creation, utilization and dissemination of knowledge is characterized by a low rate of cooperation and knowledge supporting the usage already created in the regions. The hypothesis within this case study was not approved.

IV. Lack of financial funds poses a barrier against creation, gathering and dissemination of knowledge. The case study did not approve this hypothesis.

V. In general, the state does not donate the enterprises during creation, processing, using and dissemination of knowledge. The case study did not approve this hypothesis, but it neither denies it, because the enterprise did not ask for donation during the project realization [10]. ilarities in the time parameters of the knowledge management process.

\section{Discussion and conclusion}

Technological know-how is considered as a major factor in a long-term growth and prosperity of enterprises, regions and countries. The project REDIPE presents the way of realization of the knowledge diagnostics, the knowledge processing and the knowledge dissemination. The mechanism of diagnostics, processing and dissemination in enterprise innovation processes are different in each region. There are different conditions under which diagnostics, processing and dissemination take place in each region. The research in the Zilina region was focused on examining the impact of the regional environment (in the area of knowledge) in the inno-

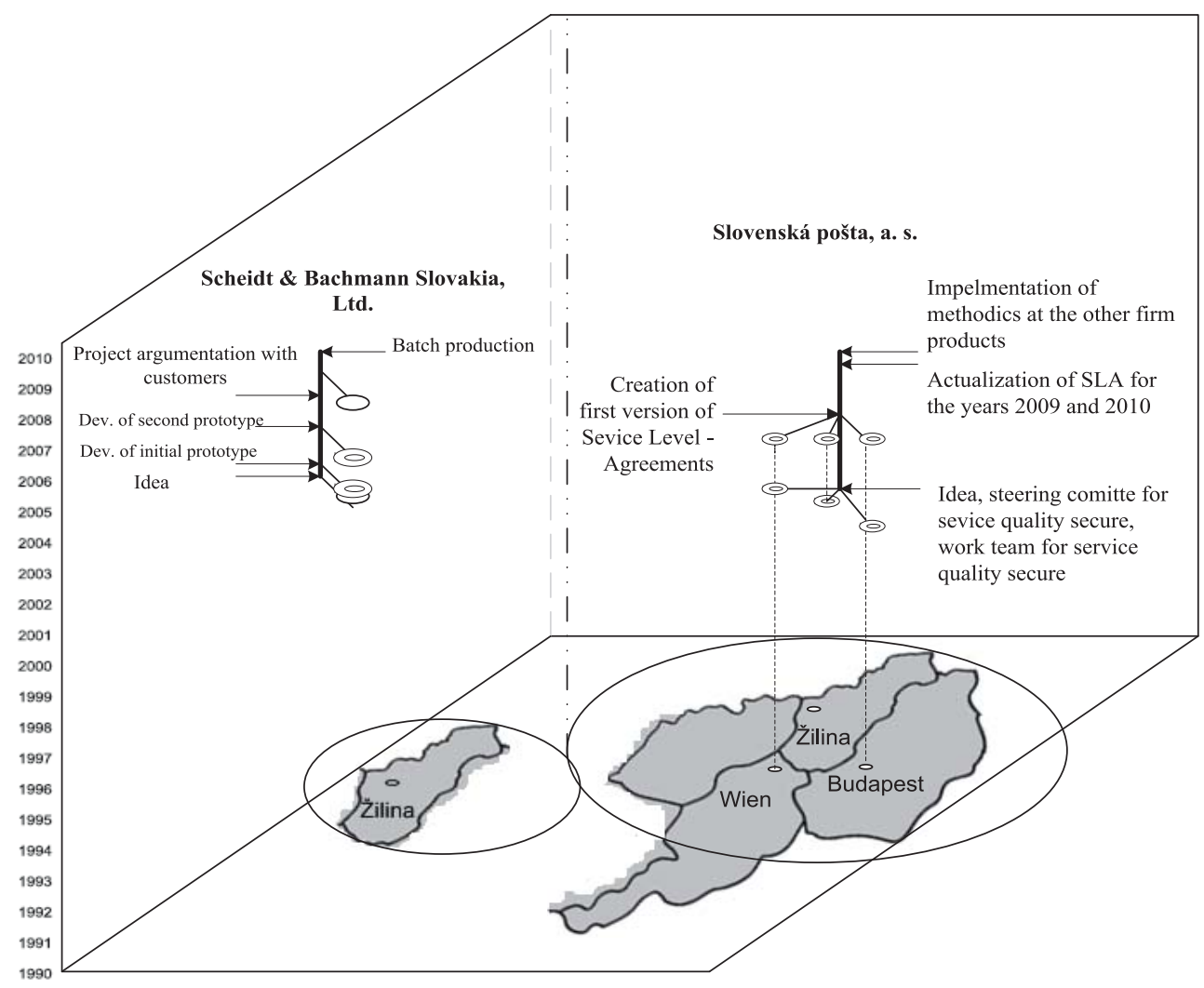

Fig. 2 Time-spatial map of knowledge processes in Scheidt \& Bachmann Slovakia, Ltd., and Slovenska posta, a. s. [10]

Fig. 2 presents a time-spatial map of knowledge processes in selected enterprises from the ICT sector of transport and logistics sector.

As we can see from the time special knowledge maps, there are obvious differences between the enterprises in the spatial scope of creation, processing and dissemination of knowledge and sim- vation process of the enterprises in the ICT sector and transport and logistics sectors.

As the research shows, both sectors were affected by the knowledge-based processes in their enterprises' history. As an example, the economic dimension of the ICT sector is shown in Fig. 3, from which it is clear how the sector has evolved from the year 1980 to the present. 
Based on the results the following can be stated: "Creation, processing and dissemination of knowledge is not a simple and automatic process. Knowledge is generated collectively. Within this process interaction and exchange of ideas take place among participants. It is also confirmed that the creation and dissemination of knowledge in space require financial expenses following from the interaction of participants. Economic activities are concentrated in space because within the sectors observed in the Zilina region, imitation and mutual studying occur more often and faster. It is obvious that under such conditions the enterprises cannot be considered as single units, but they are closely connected with other firms (suppliers, competitors), customers, private and public organizations. Firms in both sectors combine sources inside a firm (education, research and development) with acquisition of external sources of knowledge. It is evident that the relation of external and internal knowledge differed in the subject sector. It depended on

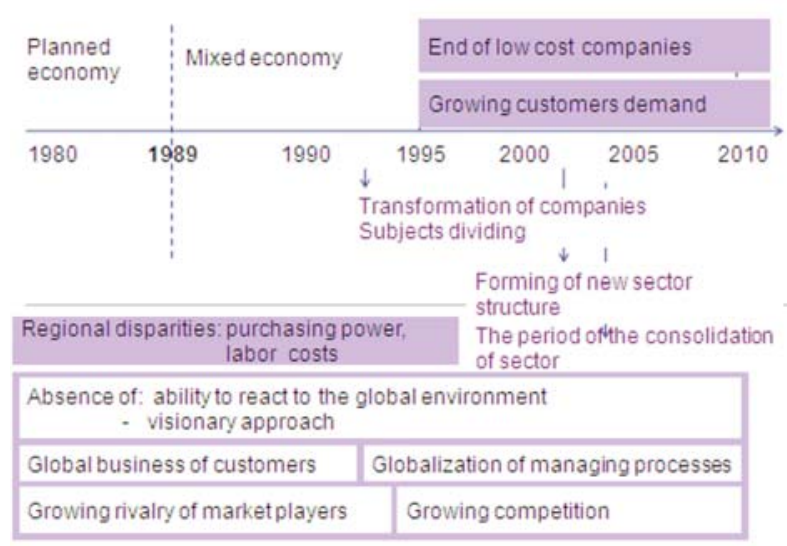

Fig. 3 Economics dimension of the Zilina Region research in ICT sector [4] expenses to get external knowledge. The firms preferred an interenterprise knowledge creation.

Finally, we can state that the concept known as an "innovative milieu" is characteristic for most enterprises of transport, logistics and ICT sectors in the Zilina region. It means that the enterprises do not innovate separately, but they are part of the environment where they are established and this environment influences them significantly. The sense of the REDIPE project was to identify the key regional participants whose activity and interaction contribute to innovation performance of the Zilina region. The research of the creation process, processing and dissemination of knowledge also pointed out the concentrated relationships between commercial and academic sectors. For all regions, as well as for the Zilina region applies that for the future success of sectors in the region it is necessary to identify new directions for development, strategic partners, and to the maximum possible extent commercially evaluate new knowledge.

Achieving the objectives of the research determined the fact that the REDIPE project has got its continuation within the project "Creative economy - regional and national economic conditions and incentives - KRENAR", approved for solving during the next years by the Slovak Research and Development Agency. All the participants of the REDIPE project are going to take part in the KRENAR project.

Acknowledgment, grant support:

APVV-0101-10 Kreativna ekonomika - narodohospodarske a regionalne podmienky a stimuly.

7/KS/2012 Kreativna ekonomika a jej uplatnenie v Zilinskom regione.

2/KS/2012 Realizacia a kooperacia na uskutocneni komplexu vyskumnych aktivit vo vybranej sfere sluzieb - faza 2.

\section{References:}

[1] COREJOVA, T., IMRISKOVA, E., PODPEROVA, A.: ICT Sector Dimensions of the Knowledge Economy in Zilina Self Governing Region. Knowledge base for management - theory and practice : scientific monograph collection. Zilina : Zilinska univerzita v Ziline, 2010. ISBN 978-80-554-0296-3.

[2] PROJEKT REDIPE - Regionalne dimenzie poznatkovej ekonomiky (zakladna charakteristika projektu) / Regional Dimensions of Knowledge Economy (Basic Characteristics of the Project) - (in Slovak), 2008, cislo projektu: APVV-0230-07.

[3] COREJOVA, T., ROSTASOVA, M., CHRENKOVA, A.: Knowledge Biography - Tool for Researching the Knowledge Dynamics. Educon 2012: Collaborative Learning \& New Pedagogic Approaches in Engineering Education: intern. conference. Marrakech, 2012. IEEE, 2012. - ISBN 978-4673-1455-8. ISSN 2165-9559.

[4] COREJOVA, T., MADUDOVA, E., MOCKOVA, M.: Dynamika znalosti v sektore informacno-komunikacnych technologii v Zilinskom regione / Dynamics of the Knowledge in ICT Sector in Zilina Region (in Slovak), Regionalne dimenzie znalostnej ekonomiky, Bratislava, EKONOM, 2011. ISBN 978-80-225-3239-6.

[5] ROSTASOVA, M., CHRENKOVA, A.: K problematike tvorby a rozvijania poznatkov $v$ dopravnych a logistickych podnikoch $v$ Zilinskom regione / Creation and Development of the Knowledge in Transport and Logistics Enterprises in Zilina Region (in Slovak). Rozvoj manazmentu v teorii a praxi = Management development in theory and practice, Zilina : Zilinska univerzita, 2010. ISBN 978-80554-0294-9.

[6] COREJOVA, T., ROSTASOVA, M., CHRENKOVA, A.: Knowledge Dynamics in Transport and Logistics Sector in the Zilina region. Problems of maintenance of sustainable technological systems, Kielce: Kielce University of Technology, 2012. ISBN 978-8388906-74-9. 
[7] ROSTASOVA, M., COREJOVA, T., CHRENKOVA, A.: Dynamika znalosti v sektore dopravy a logistiky v Zilinskom regione / Dynamics of the Knowledge in Sector of Transport and Logistics in Zilina Region (in Slovak). Regionalne dimenzie znalostnej ekonomiky. Bratislava, EKONOM, 2011. ISBN 978-80-225-3239-6.

[8] SCHEIDT AND BACHMANN SLOVENSKO, s. r. o. [online]. Available on: http://www.scheidt-bachmann.sk/index.php/aktuality/20-novinky/103-scheidt-a-bachmann-slovensko-sro>

[9] COREJOVA, T., IMRISKOVA, E., MOCKOVA, M.: Dynamika znalosti v sektore informacno-komunikacnych technologii v Zilinskom samospravnom kraji na pozadi jeho historickeho vyvoja / Dynamics of Knowledge in ICT Sector in Zilina Region in Historical Context (in Slovak), Proc. of National and Regional Economics: VIII intern. conference, 2010, Herlany, Kosice : Technicka univerzita Kosice, 2010. ISBN 978-80-553-0517-2.

[10] COREJOVA, T. et al.: Znalostna infrastruktura a trajektorie znalosti v regionalnom kontexte (elektronicky zdroj) / Knowledge Infrastructure and Knowledge Trajectory in a Regional Context - e-lectronic source - (in Slovak), Zilina : Zilinska univerzita, 2011, p. 438, ISBN 978-80-554-0411-0 [Co-authors: Rostasova, M.; Madudova, E.; Chrenkov, A.; Mockova, M.; Mravcova, Z.; Padourova, A.; Holla-Bachanova, P.; Podperova, A.; Potkan, T.]. 